\title{
THE DELTA IS DEAD: Moral Ecologies of Infrastructure in Turkey
}

\section{CATERINA SCARAMELLI \\ Boston University}

(D) https:// orcid.org/0000-0001-8513-5251

When I first met Captain Barbaros, I imagined that I would sail with him from the fishermen's port in Izmir's Mavişehir neighborhood, where we would see the Aegean Sea merge with the salt marshes of the Gediz Delta. Instead, Barbaros asked me to join him on board a crowded municipal bus. As the vehicle climbed the steep hills, Barbaros pointed down at the luxury apartments near the docks where his boat was anchored. Before the middle-class complexes were built, he recalled, there had been small houses with gardens boasting delicious melons, all framed by the waterways, canals, and marshes where Barbaros fished for eels, gathered succulent salicornia (deniz börülcesi), and shared his deltaic livelihood with hundreds of species of water birds. But now, he declared, after a long silence, "the Gediz Delta is dead." Barbaros spoke to me of the marsh drainage projects that the city of Izmir had undertaken in the 1970s. By the 1990s, the coastal marshes and gardens were gone, replaced by high-rises and luxury villas guarded by private security. Barbaros and his family had moved, too, to a modest apartment up the hill.

Hoping to understand the Gediz Delta from Barbaros's boat, I had envisioned writing about a delta animated by the movement of fish, technology, sediments, boats, birds, plants, capital, bacteria, currents, and multiple waters (Barnes and Alatout 2012; Richardson 2016; Yates, Harris, and Wilson 2017). This delta, like 
other watery environments in Turkey and beyond, had also been shaped by nineteenth- and twentieth-century state-led marsh reclamation projects to obtain new land for agriculture, industry, and cities, to create new populations of national subjects, and to displace nomadic marsh dwellers (Özesmi 1999; Biggs 2010; Evered 2012; Husain 2014; Guarasci 2015; Gruppuso 2018). But in proclaiming the death of the delta from his hillside concrete apartment block, Captain Barbaros emphasized why, and to whom, these changes mattered. He assessed, in specifically moral terms, the new, precarious, and potentially mutually annihilating relations between communities of people, plants, and nonhuman animals, all enabled by changes in the delta's built environments. Barbaros, like my other interlocutors in Izmir, articulated a moral stance on the deltaic worlds of infrastructures and ecologies, both entangled and inseparable. ${ }^{1}$

In this article, I offer the notion of a moral ecology of infrastructure, theorizing infrastructure and ecology as inseparable, rather than set in opposition. I use the term moral ecologies to indicate people's notions of just relations between people, land, water, and nonhuman animals, plants, buildings, technologies, and infrastructures. $^{2}$ Moral ecologies also constitute assessments of justice and motivations for action, which concern relations between humans and nonhumans. For example, as I detail in later sections, delta fishermen made visible, writing petitions and filing lawsuits, their claims about the unjust effects of infrastructural transformation on their livelihoods and on delta ecologies. This analytic proves helpful for understanding how, and why, people confront and respond to environmental transformations in an infrastructural world. ${ }^{3}$ Building on recent work highlighting the interconnections of ecology and infrastructure (Carse 2012; Anand, Gupta, and Appel 2018; Stoetzer 2018), and on notions of moral economy (Scott 1977; Muehlebach 2012; see also Thompson 1971), I call for a more expansive anthropological interrogation of moral ecology. I propose to take moral ecology well beyond its current use in the context of peasant, indigenous, and activist resistance (Dove and Kammen 1997; Martínez-Reyes 2016; Baker et al. 2017), or deployed interchangeably with the concept of moral economy (Rizvi 2017; Campbell 2018). This intervention also invites anthropologists of science, environment, and infrastructure to take a more central role in long-standing debates over moral and ethical world-making (Mattingly and Throop 2018), as well as in inquiries into environmental ethics (Hoefle 2008; Saxena et al. 2018). ${ }^{4}$

Distinctions between infrastructure and environment no longer hold: they fold onto one another, writes Kregg Hetherington (2019), echoing the work of other recent scholars of infrastructure in and of the Anthropocene. But for Bar- 
baros, the delta did not die because it was suddenly made into infrastructure; the delta has long been infrastructural (for as long as human communities and their nonhuman companions have lived in the region). Nor did Barbaros find hope in critters thriving in the infrastructural rubble, or in weeds growing in the cracks. What does matter — with a moral urgency — for him and for others, are the contingent and unequal outcomes of particular infrastructural arrangements of organisms, materials, and economies. The moral ecologies of infrastructure I write about in this article also challenge binaries of urban and rural, resistance and hegemony, even wet and dry. Expanding the concept of moral ecology beyond its previous meaning as, broadly, resistance to capitalist processes and dispossession helps us move beyond a binary that posits ecological relations in opposition to infrastructure — or, similarly, thriving in its interstices, disrupting engineers' plans and capitalist trajectories (e.g., Bubandt and Tsing 2018). Moral understandings of ecology in the delta, I contend, are not necessarily emancipatory, inclusive, progressive, or sustainable. They are nested within capitalist processes, histories of land expropriation, class and gender hierarchies, and exclusionary ethnonationalism.

Turkey is a good place for advancing a moral ecology of infrastructure; conversely, the analytics of moral ecology illuminate the urgency through which Turkish residents have tackled questions of environmental and infrastructural change. Understandings of ecology in contemporary Turkey are mediated by the politics of large-scale infrastructure development, as well as by the rapid transformations of agrarian, mountain, coastal, palustrine, and urban environments under the Justice and Development Party (AKP) government since 2002 (Erensü and Karaman 2016; Adaman, Akbulut, and Arsel 2017). These have variedly been projects of East-West regionalism (Firat 2016) or ones of national development (Erensü 2018). Accordingly, concerns over infrastructure (especially urban, water, energy, and transportation) have come to stand in for broader claims about livelihood and democracy, and have also become vehicles for contesting state power (Firat 2016; Knudsen 2016). Yet here I move away from a focus on Turkey's large (and small) environmental mobilizations - like the June 2013 protests against the destruction of Gezi Park in Istanbul, as well as popular opposition to thermal and nuclear power plants, run-of-the-river hydropower, and mining — all subjects of generative ethnographic research (Voulvouli 2009; Arsel, Akbulut, and Adaman 2015; Knudsen 2016). I turn instead to everyday experiences and conflicts over infrastructural ecology in the making and unmaking of the Gediz Delta as a wetland, a fishery, an open-air laboratory, a transportation node, and a site for speculative real estate. While many of these changes are conditioned by national and regional policies, 
here I foreground fishermen, scientists, NGO workers, and other working-class and middle-class residents in Izmir as they reimagine their own ecological entanglement with the delta. I argue that their moral evaluations of specific deltaic configurations speak to their participation in environmental processes; in turn, these actors have transformed the delta's material landscapes and ecological livelihoods.

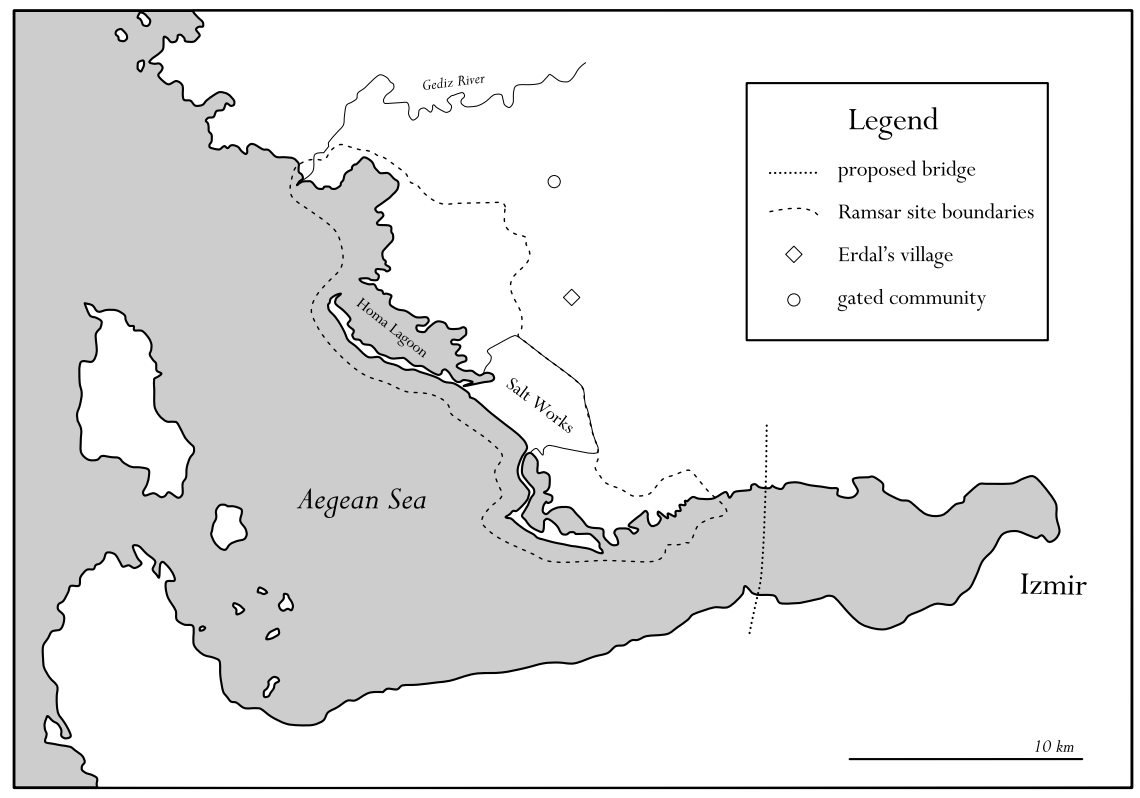

Figure 1. Map of the Gediz Delta and the Izmir Bay. Map by Caterina Scaramelli.

This argument is drawn from ethnographic research I conducted between 2013 and 2017, centered on three infrastructural ecologies of the lower Gediz Delta: a conservation wetland, a fishing lagoon, and an unbuilt bridge - sites that all overlap geographically. Fishermen, scientists, and residents in Izmir articulate varied moral claims on the livelihoods and relationships of humans and nonhumans that emerge from transformations in these sites and elsewhere in the delta. These articulations take varied forms - intimate conversations, lawsuits, scientific arguments, political declarations, and mapmaking, to name a few-and, as I will show, they enable further transformations of the built environment and its ecologies.

\section{IMMORAL INFRASTRUCTURES}

Moral ecologies reflect varying understandings about who gets included and excluded in environmental decision making, and who reaps the benefits of infrastructural and ecological transformations. One morning in March 2014, two el- 
derly fishermen and I drove past a new residential gated community in the lower Gediz Delta, at the edge of a wetland conservation area. One of the fishermen, Mustafa, gestured to the cotton fields that ended at the edge of road leading to the half-built villas, and to the ponds nearby, suffocating in green algae. "This is Mehmet Sıkı's doing," he uttered, referring to an ornithologist who had campaigned to create this protected area in the 1980s. Unlike Sıkı, Mustafa was not concerned with the marshes drying as water was redirected to agriculture, or the loss of water-bird habitats to the expanding salt industry. Rather, Mustafa bemoaned the elusive benefits of speculative urban growth, and the effects of conservation zoning. "The city of Izmir could have expanded here," he elaborated. "Then, there would have been plenty of jobs for us. But conservationists like Sıkı prohibited development. Now, there are only these small gated residences for the middle class, and they stand half empty."

Mustafa's moral claim, concerning economy as much as ecology, resonated with those of other rural residents as they considered the construction of highend gated communities since the 1990s. This urban, middle-class moral ecology counterpoised the unhealthy city with the clean countryside. Yet rural residents advanced a reverse moral ecology as they complained that the middle classes, in turn, were polluting their countryside (Datta 2014). ${ }^{5}$ But Mustafa was also concerned with the ecological effects of toxic industrial runoff flowing in the delta's coastal marshes where he fished (Scaramelli 2018a). Working-class residents like Mustafa and the middle-class residents of the new settlements (Datta 2014) both employed shifting dichotomies of healthy/toxic and legal/illegal as indicators of just/unjust landscape making. The making of these contrasts suffused divergent moral ecologies of delta infrastructure.

The other fisherman, Erdal, also found fault with the residential development. "Look," he declared. "All these houses were built illegally. The building cooperative made a huge profit, but we won't. They should not be here. This is not environmental conservation! The delta's management plan was made by people who never even come here; they just looked at their computers in their air-conditioned offices. They never talked to us. They don't know the delta.” Erdal articulated a discomfort with classed forms of environmental expertise: even as an experienced fisherman, and the elected fishermen's cooperative representative, he could not participate in an equal dialogue with scientists and bureaucrats about the possible futures of the delta. Contestations over infrastructure constitute new political collectivities (Coleman 2017), and the networks people create, maintain, or work to exclude others from, become invisible infrastructures themselves (Simone 
2004). Erdal was similarly involved in a long struggle with the university and the conservation area's management over a nearby fishing lagoon, which I will detail in a later section.

Conservation scientists, too, understood wetland ecologies as infrastructural, political, and moral. During an interview I conducted in his university office in winter 2014, Mehmet Sıkı recounted "irrigating" the protected wetland following a moral imperative to safeguard Turkey's natural and national wealth, and the livelihoods of hundreds of thousands of birds in the delta. Following his recommendation during periods of drought in the 1990s, the State Water Works (DSI) built a water canal and installed a water pump to provide "much-needed" fresh water to the marshes. Sıkı had envisioned it as an underground conduit, but the DSI had instead constructed an open canal from which, Sıkı alleged, local villagers illegally (and immorally) extracted water upstream of the drying and dying marshes.

As pumps and canals irrigated the wetland, the lower delta's water was being redirected to sites of water-intensive industrial and agricultural production, which, in turn, released agricultural and industrial pollutants. Moving flows of water and sediments thus simultaneously produced, sustained, and endangered the delta. Sikı's vision of a wetland's moral ecology was predicated on infrastructural

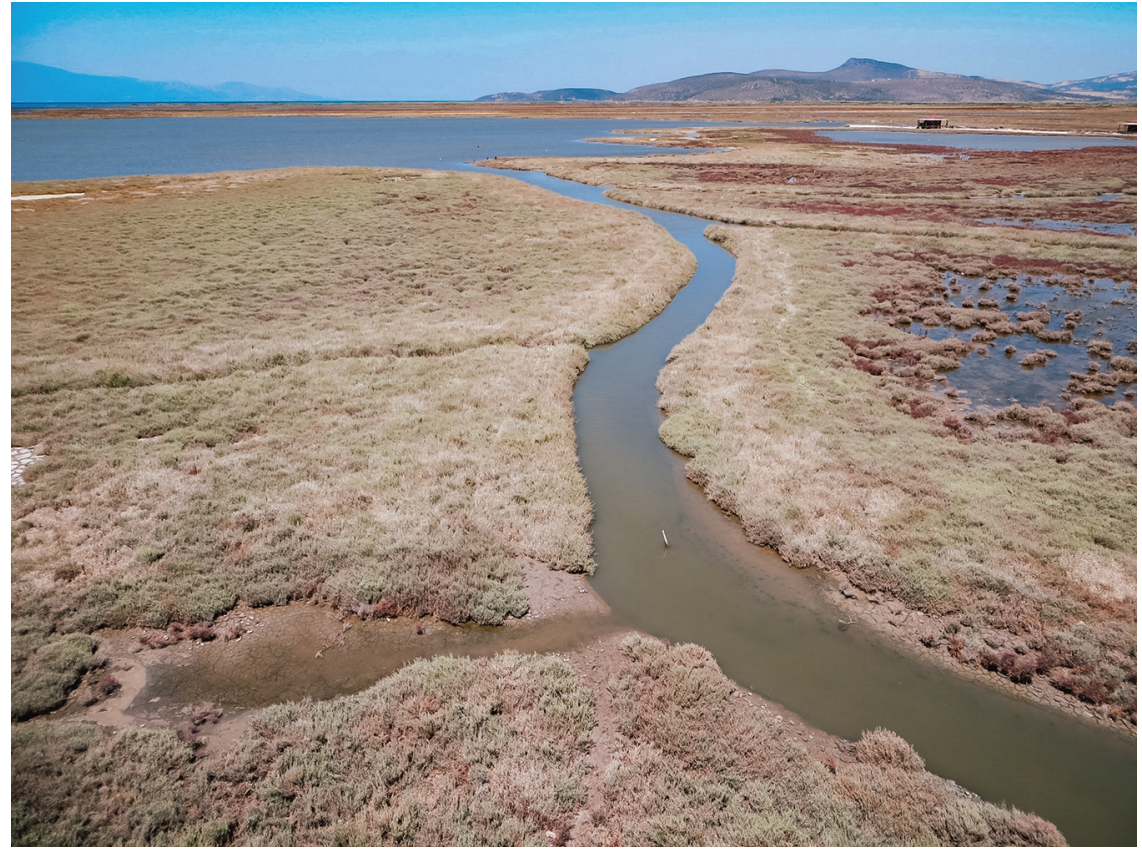

Figure 2. Salicornia, salt marshes, and fishing huts in the conservation area. Photo by Caterina Scaramelli. 
remakings that privileged putatively native species. Irrigation infrastructure that contributed to drying the marshes, he believed, could also be used to the opposite effect. He saw the gated community under construction as constituting an obstacle to wetland conservation, even as the conservation area itself increased its real-estate value.

These infrastructural ecologies presented different moral quandaries for residents, as my conversation with Mustafa and Erdal exemplified. Neither conceived of delta ecology outside of its built infrastructure, yet they saw different connections and attributed contrasting moral salience to the changing delta. For Mustafa, the gated community and the toxic sludge flowing from upstream factories into the delta's fishing grounds were indicators that planners and managers had excluded people like him from their visions of the delta's future. For Erdal, the residences offered a blatant example of the shortcomings of environmental conservation and epitomized the reckless practices of the Turkish construction industry. Both men worried that residential infrastructure in the delta left less space for their livelihoods and for their ability to make claims heard across bureaucratic and economic hierarchies. These constituted moral claims about the place of the rural working class in transformations of urban form, environmental governance, and agricultural infrastructure.

\section{MORAL ECOLOGIES BEYOND RESISTANCE}

My understanding of moral ecology goes beyond dichotomies of anticapitalist resistance and supposedly immoral ecologies. Focusing on infrastructural ecologies helps me broaden the scope of this analytic for Anthropocenic ecologies (e.g., Scott 2017), including infrastructure work. Erdal and Mustafa did not articulate a critique of capitalist and neoliberal systems of resource use (Igoe and Brockington 2007) but, rather, remained embedded within them. Neither did they posit infrastructure as destructive of ecology: in different ways, they understood them as coproduced. Anthropologists have often foregrounded the damaging effects of infrastructures_-including river dams (Errington and Gewertz 2018), orchard fences (Bird Rose 2010), landmines (Kim 2015), and flood shelters (Cons 2018) threatening the livelihood and existence of human communities, nonhuman animals, plants, and agrarian landscapes. Alternatively, studies have called attention to emergent ecologies that (somewhat unexpectedly) thrive in infrastructural rubble and ruins (Tsing 2015; Stoetzer 2018) ${ }^{6}$ and in infrastructures that unintentionally become habitats for nonhuman creatures, such as water sewers (Bruun Jensen 2017). In these studies, ecological relations are often described as either 
vulnerable to or able to transcend infrastructure; conversely, infrastructure is generally cast as dominant, hegemonic, and oppressive. ${ }^{7}$ My research demonstrates the mutual constitution of ecologies and infrastructures, rather than their opposition, as conduits for moral claims about human and nonhuman livelihood. Here I am also drawing from environmental histories, which have long cast environments as mutually constituted with human-built infrastructures (White 1996; Blackbourn 2007; Ritvo 2009; Pritchard 2011). ${ }^{8}$ I propose leveraging the analytics of moral ecology to help us see the different ethical visions that suffuse ecological relations in their infrastructural transformations. ${ }^{9}$

Anthropologists have often cast moral economies, across time and space, as different appeals for justice: calls for equitable access to land, for example, or fair remuneration for work (Edelman 2005). ${ }^{10}$ In his analysis of eighteenth-century bread riots in England, E. P. Thompson (1971) argued that they expressed a collective consensus about legitimate and illegitimate practices of bread making and distribution, as well as communal norms and obligations. Writing on peasant rebellions in Burma, James C. Scott (1977) redefined moral economy as a notion of economic justice that responded to the exploitation wrought by colonial transformations of labor and land. ${ }^{11}$ In extensive contemporary anthropological use, the concept highlights the recognition of reciprocal obligations and the fostering of social relations. The religious evaluations of new capital and profit in a Turkish village of carpet weavers, for instance, constitute one particular moral economy (Hart 2013).

Moral economies are often seen as responding to immoral practices of profiteering and the alienation of capitalist markets and neoliberal restructurings. Yet Thompson $(1971,79)$ emphasized moral economies as a shared consensus as to what constitute legitimate or illegitimate practices: "definite, and passionately held, notions of the common weal." Indeed, many anthropologists have emphasized the embeddedness of notions of morality to hegemonic political and economic transformations (cf. Polanyi 1957). For example, Andrea Muehlebach's (2012, 20) study of Italian neoliberal transformations has foregrounded the ongoing relevance of moral practices to postwelfare economies, "a form of ethical living that appears as the negation of and yet is integral to neoliberalism more broadly conceived." Similarly, Heather Paxson (2013) found that artisanal cheesemakers in the United States staked moral claims about their work that were grounded in the specifics of their production ecologies and within economic and agricultural systems. Their moral practices involved working with multispecies collaborators, (post)industrial technology, tacit knowledge, and market networks. I build on these insights to 
expand the scope of moral ecology: this analytic helps anthropologists theorize the mutual obligations, affective relations, and valuations among humans and nonhumans. I expand the moral economy by taking into account relations with other organisms, material transformations, and symbiosis. And, I suggest, moral ecology should move beyond its current focus on resistance.

In recent anthropological scholarship, moral ecology has denoted practices protecting collective resources and sustainable and reciprocal relations between environments and societies, resisting against capitalist and corporate expropriation (e.g., Martínez-Reyes 2016; Baker et al. 2017). This use, however, tends to reproduce a dialectic of ecological morality defined as resistance to the immorality of markets, states, or corporations. This perspective ultimately results in a predetermined understanding of moral claims, and fails to account for the situated norms and values embedded in capitalist, corporate, and neoliberal transformations of environmental relations. In my use of the term, moral ecologies do not simply denote traditional subsistence practices and indigenous ontologies counterpoised with, for instance, high-yield seed varieties (Dove and Kammen 1997) or bounded conservation zones (Martínez-Reyes 2016). Rather, I see these modern projects, too, as forms of moral practice and productive of new environmental subjectivities (Agrawal 2005). ${ }^{12}$ The moral notions and claims of fishermen, city planners, and scientists emerge alongside (and do not simply resist) infrastructural transformations of the Gediz Delta, and all groups actively participate in these changes. The following sections will support this claim.

\section{A CHRONICLE OF DESTRUCTION}

On a sunny spring morning, I was driving on a gravel road with my friend Emre, a biologist, following a narrow strip of land separating a lagoon from the Aegean. Delta residents knew the lagoon as Homa, but a sign marked it as the “University Aquaculture Department's Lagoon." As we drove, Emre pointed at floating foam and trash, coming from a new road construction, which had further separated sea and lagoon waters and drastically reduced circulation within the lagoon. An underground conduit connected the lagoon to an abandoned salt pan, where white and brown organic matter was pushed by the wind from the lagoon into the channel, and accumulated in one corner. Our road ended at the fish traps: a long metal structure across the shallow mouth of the lagoon. Near the traps stood a dilapidated one-story building.

We boarded a small inflatable boat to reach the other end of the sandbar, beyond the fish traps. Wading ashore, I struggled to keep up with Emre, our bare 
feet pricked by sharp shells and stones. Sitting down on a bush of red and green salicornia, I made an inventory of trash: plastic flip-flops, Lycra and woolen rags, beer and water bottles. Meanwhile, where lagoon and sea waters merged, Emre was counting a colony of deniz kirlangicı (sandwich sterns). Emre's perception was synesthetic: he used his eyes, binoculars, ears, notebooks, and the intimate knowledge of this lagoon, earned through decades of fieldwork. "To recognize birds," he told me another day, "is to know birds the way you know a close relative, a friend, a loved one. You have to know their ruh, soul."

Emre's knowledge of the delta was based on his doctoral research, but just as much on years of living and working in the delta, developing emotional and personal attachments to its human and nonhuman inhabitants - what the historian of science Robert E. Kohler (2011) has called "residential” scientific practices. He had, for instance, helped a delta village's headmen draft petitions to the National Parks Bureau to demand grazing rights for cows and sheep in the protected area (to no avail). His practices of tracing the delta's landscapes and social relations, which he knew intimately and bodily, into the abstract representations of ecological transects, bird counts, maps, diagrams, scientific papers, and data sets might also recall Erik Mueggler's (2011) account of botanists in East Asia. Like delta farmers, Emre knew what to forage: whenever I accompanied him during a fieldwork outing, he gathered wild mushrooms, asparagus, salicornia, almonds, and bitter and tangy leaves. He usually rode his bike from home to the conservation headquarters, often chased by packs of stray dogs roaming amid cotton fields and farmhouses. He and his wife had recently moved to a new middle-class residential community in the lower delta. Most other units lay empty, purchased as investments during Turkey's recent economic bubble, now burst. In this speculative infrastructure, they grew grapes, raised chickens, and fed feral dogs.

Only sailing back at sunset did I realize that our work also chronicled a moral ecology of changing infrastructure. Homa's waters were rapidly becoming sea, as waves and wind eroded the lagoon sandbars. Emre explained that agricultural infrastructure had severed the lagoon from the Gediz River estuary. Removing dikes and drainage canals would once again open the delta's marshes to their seasonal hydrological pulsing and allow freshwater to flow into the lagoon. This, he acknowledged, would prove impossible. But many species of birds continued to make the lagoon their home, and some infrastructural changes risked destroying their habitats, while others would allow for their flourishing. For example, two artificial islands built in the salt pans provided a popular nesting ground for thousands of flamingos. Different environmental advocacy groups heatedly contested different 
projects of lagoon restoration. Our fieldwork would help Emre and friends at an environmental NGO draw a map showing bird-nesting sites that would be destroyed by the university management's restoration project. This work marked a moral vision of nonhuman livelihood (at the scale of flocks, ecological habitats, and species), entangled within a spectrum of more or less desirable infrastructural configurations, all of which were lived ecologies.

\section{A NATURAL AND NATIONAL WETLAND}

The transformation of the Gediz Delta's agricultural fields, saltworks, wet meadows, lagoons, salt marshes, docks, reed beds, lakes, canals, and mudlands into a wetland had begun in the 1980s. Local ornithologists and hunter organizations mobilized against the expansion of the saltworks of Çamaltı on nearby marshes. ${ }^{13}$ In his field research, starting as a doctoral student, Mehmet Sıkı (1997) identified 183 bird species, 50 of which were laying eggs in the delta's reed bed. Sıkı and a colleague published a plea in the Turkish magazine Science and Technology: "We expect that the Çamaltı management will recognize the protection of the wetland area inside the salt pans, which contributes with her unique and special value to the beauty and wealth of our country. We urge management to undertake the important duty of and stop the expansion of the salt-works" (Sıkı and Baran 1984, 5). As a habitat for hundreds of species of birds, they claimed, a protected wetland area of natural and national value needed to be established. Other university scientists joined the campaign for the conservation of the area, which, in 1998, also became a Ramsar wetland of international importance. ${ }^{14}$

In appealing to the national value of the delta, rather than to international science, Sıkı situated wetlands as part of a Turkish nationalist discourse on nature's value - one that could be appraised through the prism of science. This approach reversed the older paradigm positing green forests as a symbol of national civilization, while unproductive marshes and deserts represented backwardness (Özkan 2018). Sıkı would later also campaign for the removal of a eucalyptus forest planted on the marshes. However, beyond appeals to nativism and nationalism, Sıkı largely narrated his role in the conservation of the wetlands in explicitly moral-ecological terms. As Sıkı $(1994,7)$ wrote on the expansion of the saltworks on the marshes, for example: "I was deeply affected, and I believed that I could not remain an outside observer."

Sıkı's and others' appeals led to the creation of several overlapping conservation zones, and to material transformations in the delta's wetlands, shaped by scientists' moral visions of multispecies ecologies. ${ }^{15}$ Alongside university scientists, 


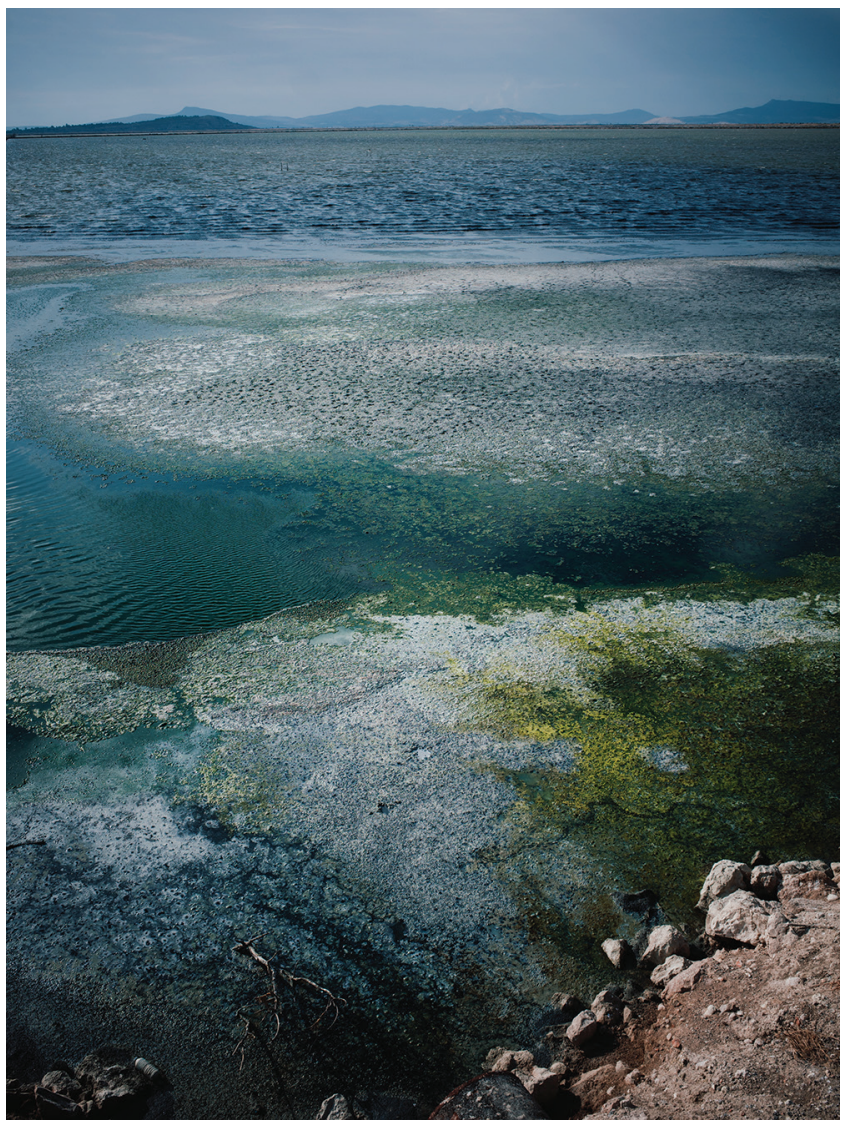

Figure 3. Homa Lagoon: In the wetland, water is always multiple. Photo by Benjamin Siegel.

Turkish environmental NGOs began to take an interest in the wetlands, advocating for their conservation and filing lawsuits against new construction within the protected areas. These groups, however, staked competing claims on the changing ecological infrastructures of the delta, as I will describe in the next section.

\section{THE LAGOON TRAP}

When I met him in 2014, Erdal, one of the two elderly fishermen introduced earlier and the head of the delta villages' fishing cooperative, was leading a prolonged crusade against university managers who had prevented fishermen from accessing the Homa lagoon fisheries. Over centuries, Homa had been made and remade around the seasonal flows of water and fish. Fishermen collectively maintained the lagoon using karg1 (Arundo donax), saz (Phragmites australis and Juncus sp.), and stones; these were mobile infrastructures moved seasonally. In early spring, 
schools of fish swim through a narrow inlet into the lagoon to feed and reproduce in the shallower, warmer, and less salty waters. In late fall, as lagoon waters cool, those fish prepare to swim out toward warmer and deeper sea waters and get caught. Lagoons, in a sense, are traps.

One morning, over cups of tea and börek (a popular savory pastry) in his neighborhood's teahouse, Erdal told me that his parents had not been fishers; rather, they had always associated fishing with the Greek Orthodox villagers in the delta. ${ }^{16}$ The name of the delta's biggest fishing lagoon, Erdal continued, was a Greek word: Homa meant "earth," owing to its shallow and turbid quality. Greek Ottomans had in fact dominated maritime professions, such as sailing, fishing, and oaring, until the 1920s (Goffman 1990). But unsurprisingly, Erdal did not mention the violent deportations and forced exchanges that led to the eradication of the Greek Orthodox population between 1914 and 1923. ${ }^{17}$ No scientist, activist, or fisherman I had talked to had ever mentioned to me the Greek history of Homa. In the remaking of the delta as a site of national value, older cosmopolitan histories of landscape use, and particularly those uncomfortable to narratives of ethnic nation-state formation, had been elided, thereby showing that ethnonationalism is bound to moral claims about ecological and infrastructural form.

Erdal was born in the delta village of Tuzçullu, then known for sheep farming and camel caravans that carried, among other goods, salt from the nearby mines. The family claimed nomadic (yörük) heritage, and Erdal was a shepherd. As a teenager, he had moved to the expanding industrial outskirts of Izmir to work in a paper factory. On retirement, he bought a small fishing boat, nets, and other equipment, and joined the local fishermen's cooperative. Erdal's son, too, had only become a full-time fisherman after quitting his job in an auto shop in the wake of a fight with his boss. Only at sea, he told me, lighting a cigarette as I pulled nets of squid, algae, and crustaceans to the boat, did he feel free and at peace. From the deck, he threw small fish into pelicans' open beaks. The birds knew to follow his boat, he said, and would be ready to jump and swallow the fish.

Erdal's family story resembles that of many other landless (or smallholder) peasants in the lower delta: old and young men (and a few women) at sea during the fishing season, working flexible or seasonal jobs, and, if they have the capital, opening fish restaurants in new lower-middle-class compounds. Tuzçullu fishermen, Erdal told me another day, specialize in fishing octopus and squid in the Izmir Bay and in lagoon fishing in Homa. Erdal's son and daughter-in-law had worked precarious seasonal jobs and had recently opened a fish takeaway, but they aspired for the next generation to achieve more secure employment as state em- 


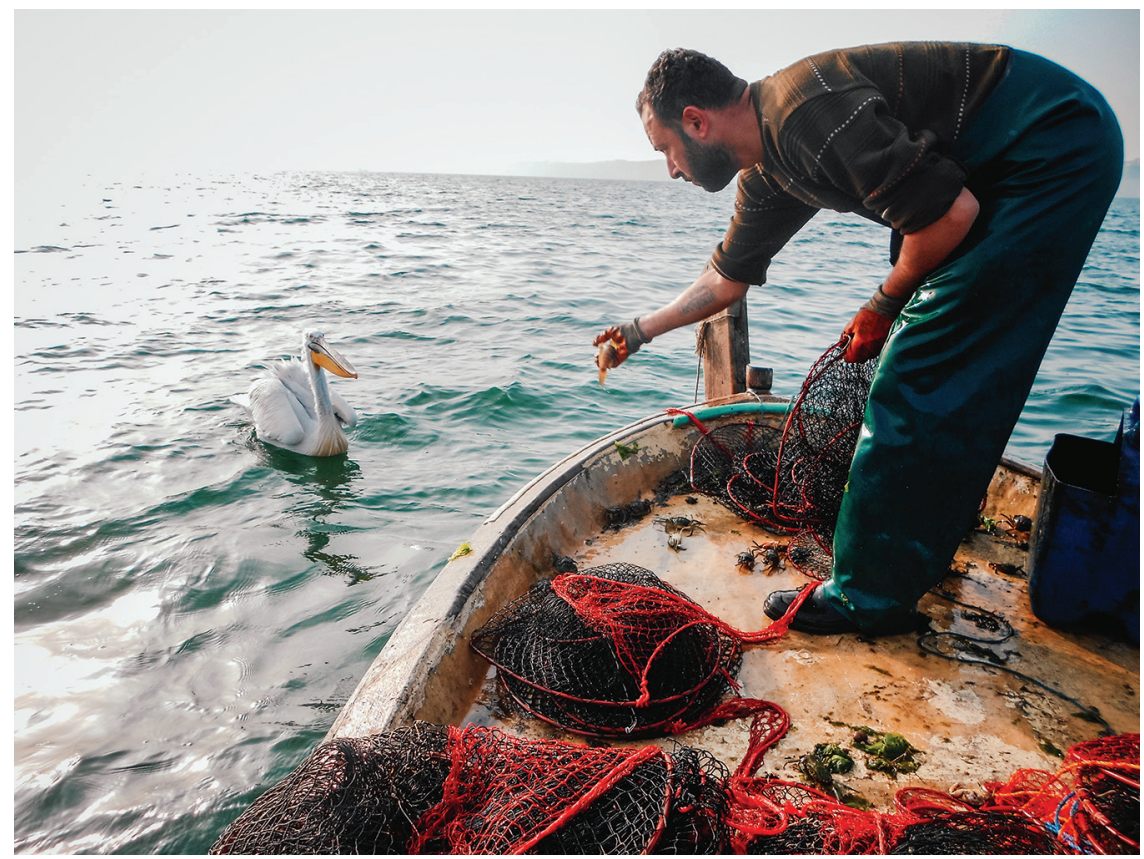

Figure 4. Fisherman shares the day's catch with a pelican. Photo by Caterina Scaramelli.

ployees. Much as fish are trapped in the mobile infrastructure of the lagoon seeking warmth and food, Erdal told me en route to the train station after a fishing outing, so, too, had he felt trapped in his factory job. Extending Erdal's comparison, both fish and fishermen were caught in yet another trap: the changing infrastructural bureaucracy of the lagoon.

\section{UP TO CODE}

Homa is a lively delta infrastructure, made and remade through flows of water, labor, capital, and regulations, as well as through changing "environmental imaginaries" (Yeh 2009, 107): the layering of infrastructural projects on landscapes. In the late nineteenth century, after city engineers redirected the Gediz River northward to prevent the Izmir Bay from becoming too shallow, the sea started eroding the lagoons (Doğer 1997). The expansion of drainage and irrigation canals and the growth of urban districts in the twentieth century both served to reduce freshwater flows. Lagoons became shallower, polluted, saltier, warmer, and eutrophic. One Izmir lagoon was turned into a beach, then a trash landfill, and then a leafy park. In the 1990s, the municipality dredged the inner bay lagoons.

The remaining delta lagoons were caught in contestations over access to infrastructure and ecological change. In the 1980s, as ornithologists began mobi- 
lizing against the expansion of the Çamaltı saltworks, the university set out to acquire Homa, with the aim of building a scientific fishery. The Department of Fisheries and Aquaculture won a long legal struggle against the fishing cooperative (Alpbaz 2012), and Homa became the only university-owned lagoon in Turkey. Members of the cooperative could keep fishing, but the university would retain a large share of the catch. In addition, it would take over the infrastructural maintenance. Fishermen, however, told me that university staff could not or would not do the seasonal work in the lagoon as they had done — a neglect that, they contended, had accelerated the deterioration of the lagoon ecosystem.

In December of 2009, a winter storm destroyed the access road. The university placed a locked gate at the lagoon entrance. Passes were distributed to authorized fishermen traveling to the docks beyond the gate, but the lagoon remained off limits. Eating fried fish in his tiny restaurant, Erdal's son told me that he once tried to get in using his father's pass and was banned from the site. In our conversations in the university department in the winter of 2014, the lagoon managers (all aquaculture professors) explained that they closed access to renew the lagoon's infrastructure - the research building, road, barrier islands, and the fish trapsand to prevent the fisheries' depletion.

During an interview in his office in spring 2014, the department's head and lagoon manager characterized the fishermen then fighting to regain access to the Homa lagoon as cahil (ignorant) and güvenilmez (untrustworthy). A colleague declared, without irony, that the university had "brought the lagoon up to code." He pulled out a booklet on the legislation concerning the spacing of steel bars in fishing lagoons and gave me a copy to keep. In seeking to construct stable infrastructures in unruly, unpredictable environments, experts also reproduce their own notions of politics (Harvey and Knox 2015). In this case, university lagoon managers made an argument about the positive ecological effects of their new and supposedly up-to-code infrastructure to justify restricted access. Private security guarded the lagoon; the guards watched TV in the damp and dilapidated building, making tea on a gas stove. At night, one of them told me, they had witnessed intrusions by "illegal" users, sometimes armed. Unable to access the lagoon with the banned fishermen, I accompanied a microbiologist and her student on a dinghy as they fished for valuable organisms, filtering water with a makeshift tool of cheesecloth, water bottles, and a bullet cartridge. Back in the lab, she showed me the phytoplankton through a microscope, describing its potentially lucrative industrial applications. ${ }^{18}$ 
In 2010, the municipality restored the lagoon sandbar with truckloads of rubble from demolished informal neighborhoods that had been constructed around the ancient Agora, including pieces of the Agora itself. The university, sued by the provincial government, had to pay a hefty fine, remove the rubble, and rebuild the sandbar (Karademir Erol 2012; Kizılkaya 2012). The State Water Works installed a pump to allow seawater to enter the lagoon, as the inlets had been closed by the new road. In 2015 the university's vision for lagoon restoration entailed using mud extracted from the dredging of the bay to make new islands for nesting pelicans. It also involved redirecting water from wastewater plants into the lagoon through an underground canal. The project included a circulation canal dredged at the bottom of the lagoon - the first in the world, university scientists boasted.

When the university did not allow fishermen back into the lagoon, Erdal penned letters to state officials and institutions and held meetings and press conferences. Yet his petitions were to no avail. He and other fishermen showed me that the renovation project had radically changed the infrastructure of fishing and flow. The work that the fishers had performed seasonally to maintain water circulation and fish populations - opening and closing the inlets between lagoon and sea through the use of reeds and rocks - had been replaced with less mobile steel, cement, and gravel. The renovation works and a new management model aimed to create a new moral ecology as a model ecosystem (Paxson and Helmreich 2014): a reengineered wetland laboratory and living space for university scientists, birds, and microorganisms. This change was not just a word game: the wetland denomination also defined who (humans and nonhumans alike) would, and could, shape its material and symbolic futures. The argument was fought through envisioning new infrastructural transformation producing different (and differently inhabitable) ecologies, all of which carried competing moral stakes for fishermen, scientists, residents, and environmental advocates.

\section{DON'T TOUCH MY FLAMINGO}

On May 4, 2017, three civil society organizations and eighty-five citizens filed a lawsuit in Izmir's district court against the Ministry of Environment and Urbanization. The 2014 revision of Turkey's wetland legislation had eased new infrastructure development in protected areas. This coalition was now contesting the ensuing approval of the Environmental Impacts Assessment for a highway bridge over the Izmir Bay. In February 2017, my friend Zeynep told me, the National Wetland Commission had changed the Gediz Delta's conservation boundary near the area scheduled for bridge construction from a "strict preservation zone" 
to an "area of controlled use." This had simplified the approval process for infrastructural development; in August, the NGOs filed another lawsuit against the new conservation zoning.

The contested project consisted of an eleven-kilometer highway, including a bridge, tunnel, and an artificial island in the shape of a moon and star. These were the emblems found on Turkey's flag, but friends told me that the island would be made in the shape of a lightbulb: the symbol of Turkey's ruling party, the AKP. The rumor about the "real" shape of the island suggested that the project had come to stand for the ruling party both as its material incarnation in the environment and as an authoritarian mechanism for the exercise of centralized power. The bridge would cross from the southern bay to its northern shores in the Gediz Delta and then connect to the new Izmir-Istanbul highway. The project had been at the forefront of the AKP's Binali Yıldırım's losing municipal election campaigns in 2011 and 2014. ${ }^{19}$ Its supporters referred to the project as a "necklace" for the city, and the bridge was named as one of the AKP's goals for the Turkish Republic's centenary in 2023.

Zeynep, a civil society organizer and environmental social scientist, emailed me the lawsuit document. I read it as a moral ecology couched in the language of law to protect human and nonhuman livelihoods, and Zeynep agreed with my analysis. Infrastructure, anthropologists write, mediates state and corporate power, collective actions, and subjectivities, often becoming visible when things do not work as planned. ${ }^{20}$ For instance, failing urban water infrastructure reveals political systems that leave their citizens to fend for themselves (Schwenkel 2015) and generates new everyday practices of family and neighborhood care labor to tame unruly sewage and ill-fitting connections (Farmer 2014). While access to water infrastructure may be central to informal settlers' claims of belonging to a polity (Anand 2011), water technologies also produce new moral subjects (von Schnitzler 2013). In this case, residents formed new alliances mediated by a shared concern with an unwanted infrastructure. They did not reify boundaries between environment and politics (Stamatopoulou-Robbins 2014) but, rather, emphasized the infrastructural politics of environment. The bridge, the plaintiffs declared, citing Izmir's latest urban plan, was incongruous with the city's transportation needs. Yet most of the opposition to the bridge was not couched in economic or planning arguments, but in ones of ecology and livelihood.

The bridge project, poised to increase water pollution in the Izmir Bay, would result in destruction of the ecological life and biodiversity of the Gediz Delta's wetlands. In contesting the bridge, plaintiffs leveraged the international 
Ramsar status of the delta's wetlands, alongside other national nature conservation statutes. The lawsuit emphasized the role of the delta as a feeding and nesting ground for hundreds of bird species, including one third of the Mediterranean flamingo population. In the wake of the June 2017 court decision to reassess the Environmental Impact Assessment (EIA), Zeynep and other friends staged a social media campaign centered on two connected slogans: flamingoma dokuma, "don't touch my flamingo," and Gediz Deltası hepimizindir, "the Gediz Delta belongs to all of us." In a press conference I attended in June 2017, the environmental NGO's spokesperson declared the project would "cause one of the biggest destructions ever seen in world history."

The flamingo, a mascot of wetland conservation in Izmir - and tangible proof of its putative failures and successes - had become a charismatic symbol of the varied nonhuman livelihoods potentially destroyed by the planned project. Yet it was not simply a charismatic animal leveraged instrumentally (cf. Takacs 1996). At stake in the stated concerns for ecological life were also deep-seated, emotional, cultural, and ethical concerns with (human) power and with the effects of the authoritarian planning of infrastructure. These were questions of infrastructural moral ecology. In July and August of 2018, a court-appointed panel of experts stopped the project for its lack of compliance with environmental protection regulation in the wetlands (Karakoyun 2018). In October, the court held that the project's EIA was invalid, noting its negative impact "on a very important nature conservation area, protected by international environmental conservation agreements as well as by other protection statuses" and "on water temperature and circulation in the bay, which would result in the disappearance of artemia [brine shrimp], which are fundamental to the food chain of flamingoes, and that would also cause damage to fragile ecosystem equilibria.” The general election of June 24, 2018, which resulted in the victory of the People's Alliance (Cumhur Ittifakı), an electoral alliance between the AKP and the Nationalist Movement Party, ushered in sweeping constitutional change and an authoritarian presidency — soon followed by the rapid fall of the Turkish lira. In its aftermath, media outlets devoted less attention to the bridge. But for Zeynep and others, this outcome offered a glimmer of hope and resilience.

\section{CONCLUSION}

Izmir residents, fishermen, NGO workers, scientists, and bureaucrats understand the Gediz Delta as a livable place by invoking infrastructural remakings of specific relations. Infrastructures are ecological, inhabited, and produced through 
work, power, and capital. Infrastructures, I contend, exist in varied relations to environments and ecological relations, and in ways that are not merely metaphorical. Given its broad analytical purchase, it is unsurprising that anthropologists see infrastructure as at once "generative and degenerative; constructive and destructive; future oriented but ultimately fleeting; fluid and mobile yet inflexible; and sometimes obdurate to retrofitting" (Howe et al. 2016, 559). In the Gediz Delta, these apparent contradictions (inflexible and mobile, for instance, or futuristic and traditional) arise as scientists, state officials, and residents construe varied moral notions of ecological relations and livelihoods. Perhaps the Gediz Delta is an enchanted infrastructure (see Harvey and Knox 2012), creating a sense of shared social good and holding together competing hopes, an enchantment that involves ecological relations alongside social or political ones. As opposition to the bridge and concerns raised by the gated communities make apparent, the movements that delta infrastructures allow — of energy, capital, media, people, and goods - also symbolize state power (Larkin 2008).

In this article, I have foregrounded infrastructures as existing within and shaping lived environments of human and more-than-human ecologies, suffused by moral understandings of normative relations and justice. In doing so, I have proposed to take anthropological theory beyond dichotomies of infrastructure and environment, demonstrating that ecologies that come to matter as moral landscapes are already embedded in infrastructure. We can only accomplish the disentanglement of infrastructure and ecology as separate categories by erasing a variety of perspectives. For example, the fishermen's cooperative argued that their infrastructural labor created lagoon ecologies viable for sustainable fishing. In contrast, university management contended that only its infrastructural renovations, "up to code," would create a valuable lagoon ecology for scientific knowledge production. Similarly, the ornithologist envisioned the role of irrigation infrastructure as sustaining bird ecologies and posited the delta's eucalyptus trees as invasive organisms to be removed. The outcome of the co-constitution of infrastructure and ecology is a moral value, in Thompson's (1971) sense of a shared sentiment (see also Fassin 2009).

A moral ecology, as I have theorized it, is both an impulse for action-Emre's mapmaking, for instance - and for the terms in which claims are made, like his vision for ideal relations between birds, fish, flows, and infrastructure. Moral ecologies are also couched in epistemological claims: Zeynep, Sıkı, and Emre all claim a scientific understanding of delta ecologies, appealing to different, and often contrasting, scientific arguments tempered with moral commitments to "good" 
landscapes. At the same time, fishers like Erdal and Mustafa counter an experiential command of deltaic flows gained through decades of lagoon-making, fishing, and seafaring labor. All of them also practice moral visions of the ecology of infrastructure as they create and sustain social relations with the delta's pelicans, flamingos, salicornia, reeds, fish, and countless other nonhuman beings while working, foraging, conducting research, spending time with family, and cultivating friendships and collaborations.

\begin{abstract}
In a Turkish delta, fishers, scientists, and residents articulate contrasting moral ecologies of infrastructure. Contesting the infrastructural remaking of delta environments, fishermen connect ecological change to the concerns of working-class livelihoods; scientists assert a unique moral authority to create new habitats for selected species; and activists couch claims of ecological justice within existing legal spaces, all against the backdrop of increasing authoritarianism and economic crisis. This article extends insights from anthropological discussions of moral economy into political ecology to advance a new theoretical understanding of environmental infrastructure. I offer the notion of a moral ecology of infrastructure, theorizing infrastructure and ecology as inseparable, rather than set in opposition. In my use of the term, moral ecologies are assessments of justice and motivations for action that concern relations between humans and nonhumans. These assessments are not necessarily couched as resistance, but also encompass hegemonic and capitalist projects. This analytic proves helpful for understanding how, and why, people confront and respond to environmental transformations in an infrastructural world. At stake in these claims are moral notions of human and nonhuman livelihoods, notions that include those of water flows, birds, fish, sandbars, trees, and others. [infrastructure; ecology; conservation; Turkey; water]
\end{abstract}

\title{
ÖZET
}

Bir Türkiye deltasında balıkçılar, bilim insanları ve deltanın sakinleri, altyapının birbirine zit ahlaki ekolojilerini ifade ederler. Her bir grubun delta ortamlarının yeniden altyapılandırılmasına karşı çıkış nedeni farklıdır: balıkçılar ekolojik değişimi iş̧̧i sınıfının geçim kaygılarıyla ilişkilendirir; bilim insanları seçili ender türlere yeni habitatlar oluşturmak için kendilerine özgü ahlaki bir otorite ortaya koyarlar; ve çevreciler artan otoriter rejim ve ekonomik krizler kıskacında, mevcut yasal alanlarda ekolojik adalet iddialarını dile getirirler. Bu makale, çevre altyapısına dair teorik yeni bir anlayış geliştirmek için ahlaki ekonomi ile ilgili antropolojik tartışmaları politik ekolojiyle ilişkilendirmektedir. Ahlaki altyapı ekolojisi kavramını önererek, altyapıyı ve ekolojiyi birbirine zit olmaktan ziyade birbirinden ayrilmaz kavramlar olarak görüyorum. Ahlaki ekolojilerden kastım, insanlar ve insan olmayanlar arasındaki ilişkilere dair gelişen adalet anlayışı ve eylem motivasyonlarıdır. Ahlaki 
ekoloji mutlaka direnç demek değildir; aynı zamanda hegemonik ve kapitalist projeleri de kapsamaktadır. Bu yaklaşımla, insanların altyapı dünyasındaki çevresel dönüşümlerle nasıl ve niçin karşı karşıya kaldıklarını ve bu dönüşümlere nasıl tepki verdiklerini anlayacağımızı iddia ediyorum. Bu iddialarda dile gelen, insani ve insan dışı geçim kaynaklarına dair olan ahlak kavramlarıdır; suların akışını, kuşları, balıkları, kıyı kordonlarını, ağaçları ve diğerlerini içeren kavramlar. [altyapı; ekoloji; doğa koruma; Türkiye; su]

\section{NOTES}

Acknowledgments I am grateful to my friends, hosts, and collaborators in Izmir, without whom this research would not have been possible. Big thanks to Anand Vaidya, Benjamin Siegel, Chris Walley, Emily Wanderer, Jessica Barnes, Jim Scott, Kali Rubaii, Namita Dharia, Nicole Labruto, Sam Dolbee, Simone Popperl, Tessa Farmer, Sophia Stamatopoulou-Robbins, and Stefan Helmreich for their generous and insightful comments. I also thank the anonymous peer reviewers and editors at Cultural Anthropology, especially Brad Weiss, for their careful reading and constructive feedback. The Yale Agrarian Studies Program provided an inspiring setting for writing and revisions. Earlier versions of this article have also been presented at the STS Circle at Harvard, the annual meeting of the American Anthropological Association, the Center for Humanistic Inquiry at Amherst College, and the Association of Social Anthropology of the UK and Commonwealth conference, and I have benefited from participants' comments and suggestions. The Wenner-Gren Foundation for Anthropological Research and the National Science Foundation (grant no. 1429914) funded much of the field research that appears in this article.

1. The terms ethics and morality are sometimes used to demarcate contrasts between personal or collective, secular or religious, general or socially embedded, unspoken or self-reflective, private or political (Mattingly and Throop 2018). This article takes moral ecology in the widest sense, beyond dichotomies.

2. In contrast with my use of the term, many others (e.g., Hertzke 1998; Swartz 2010) have theorized moral ecology using ecological models as metaphors for sociocultural processes.

3. The urgency of moral ecology is immediately apparent in contexts of infrastructural violence, such as plantations' predatory practices and the destruction of livelihoods in Indonesia (Li 2018), or oil companies' disentanglement from questions of infrastructure provision in Equatorial Guinea (Appel 2012). My interlocutors, however, would not see transformations in the delta as commensurable to nearby, starker sites of infrastructural violence, including the 2014 collapse of the coal mines in Soma that killed 301 workers. In this article, I show that moral ecologies also concern more mundane sites of infrastructural livelihood.

4. Environmental ethicists interrogate and classify in universalistic terms the premises of people's worldviews and beliefs leading to specific assessments of justice or actions, particularly in the context of intractable environmental quandaries (e.g., Boylan 2014). Anthropologists have challenged their universal premises and added ontological nuances to abstract categories and relational approaches in environmental ethics (e.g., Jax et al. 2013) and are inviting new conversations with environmental anthropologists (Saxena et al. 2018).

5. Ayfer Bartu Candan and Biray Kolluoğlu (2008) have argued that the new urban forms of middle-class gated communities and housing for the poor are interconnected. By contrast, Kimberly Hart (2017) suggests that the residents of an Aegean village that became a suburban neighborhood of wageworkers still understood themselves as independent from the state provision of infrastructure. 
6. Raymond Williams (1977) understood emergent social and cultural practices as opposed to dominant orders in a dialectic of incorporation and resistance. Michael M. J. Fischer (1999) theorized emergent forms of life in late capitalism as social mediations of science. Emergent, in the sense of processes arising unexpectedly and distinct from existing conditions, often carries a normative connotation: for example, Eben Kirksey (2015) has interpreted emergent ecologies as symbiotic associations of living creatures that disrupt the existing order, while generating new possibilities for mutual flourishing.

7. Anthropologists have theorized environmental infrastructure as the managerial notion that ecologies themselves perform the work of human-built systems, foregrounding the entanglement of the built and natural environment (Hetherington 2019). For instance, as floating rice supports the Chao Pharaya Delta's irrigation system, engineers and environmental managers envision multispecies and natural infrastructures (Morita 2017). And for environmental managers, forested land becomes part of a broader infrastructure of water provision to make the Panama Canal work (Carse 2012).

8. I also align with anthropologists like Joseph Masco (2004), who has argued that species once understood as vulnerable to nuclear contamination have become icons of ecological survival and purity in remediation zones. And I join Andrew Mathews's (2018) theorizing of landscapes as partially connected entities structured by more-than-human relations, even though he takes infrastructure as mere metaphor.

9. Moral ecologies also emerge from embodied practices of the cultivation of place, identity, and belonging, sometimes rooted in the land (Pandian 2009; Ives 2014) and sometimes flowing and sedimented in moving waters.

10. Anthropologists have recently observed a renewed attention to questions of ethics and morality (e.g., Keane 2016; Throop 2016), including in people's economic practices.

11. Scott's interpretation added an attention to specific values, emotions, and senses of justice to Thompson's focus on traditional norms.

12. Moral ecologies are also embedded in broader political ecologies.

13. People had been extracting salt in the region for centuries. In the eighteenth century, salt became an export good for global trade routes from the nearby port of Eski Foça. Extraction was controlled by the Ottoman state and actioned to local tax farmers; Greeks often ran the mines and salt pans. In Eski Foça, salt from Çamaltı, Adatepe, and other extraction sites was loaded onto ships or transported on camelback to the rail station of Menemen (Erol 2016). In the late nineteenth century, Çamaltı was turned into a centralized production system (Egemen 1946). After the Turkish Republic's 1923 founding, the Çamaltı saltworks became a state monopoly. Salt was sold only on national markets, and production decreased. Çamaltı salt continues to be used in the petrochemical, textile, soda, chlorine, and leather industries (Saltan and Okar 1968).

14. The Turkish government joined the Ramsar Convention in 1994 (Matthews 1993). In the early 2000s, as Turkey's environmental legislation came to encompass wetlands, wetland commissions were established in each province, and the national Wetland $\mathrm{Bu}$ reau drafted management plans.

15. In March 1982, Turkey's Directorate of National Parks and Hunting approved the creation of the Homa Lagoon Wildlife Conservation Area and a Waterbird Protection and Reproduction Area. In 1985, the Ministry of Culture granted the area protected status and began reforestation in the southern marshes. In 1987, the Izmir municipality named the delta a "bird paradise." This denomination was inspired by the earlier ornithological and conservation work of Kurt Cosswig (Özesmi 1999; Scaramelli 2018b).

16. Many Greek Orthodox fishermen were landless peasants who worked seasonally as sharecroppers, fishermen, and salt miners. Almost all sharecroppers in Eski Foça, for example, were Greek Orthodox (Erol 2016).

17. In the late seventeenth century, Smyrna grew from a small port into a cosmopolitan city and global maritime trade node. Its surrounding landscapes produced export goods such as dried fruits, salt, and stone (Goffman 1990; Zandi-Sayek 2012). In the early twentieth century, the forced deportations of Ottoman Greeks and Armenians, war and occupation, and population exchanges dramatically transformed the demographics of 
Izmir (Milton 2008; Meichanetsidis 2015; Erol 2016). Leyla Neyzi (2008) has argued that residents' memories of the violent remaking of Izmir from a cosmopolitan port city to a Turkish town emphasized narratives of loss even as they embraced wider nationalist stances.

18. In the 1990s, scientific research in the Homa lagoon focused on the role of phytoplankton on fish populations. In the 2000s, phytoplankton itself became the subject of research (Yazıcı and Büyukışık 2007).

19. Yıldırım went on to become the minister of transportation, AKP party leader, and then prime minister, until the office was abolished in the referendum of June 2018.

20. Anthropologists have generally understood infrastructures as networks (of people, things, and information) imbricated in political relations. Ethnographies have often focused on the things infrastructures do, the social relations and subjectivities they produce, as well as on their intended and unintended effects. This approach partly derives from notions from science and technology studies about infrastructure as invisible systems of organization embedded in social arrangements and learned practices (Star 1999) and as socially constructed technological systems (Hughes 1987). The changing meaning of infrastructure in engineering, military, development, and finance have also shaped anthropological analytics (Carse 2017).

\section{REFERENCES}

Adaman, Fikret, Bengi Akbulut, and Murat Arsel

2017 Neoliberal Turkey and Its Discontents: Economic Policy and the Environment under Erdoğan. London: I.B. Tauris.

Agrawal, Arun

2005 Environmentality: Technologies of Government and the Making of Subjects. Durham, N.C.: Duke University Press.

Alpbaz, Attila

2012 “Homa Dalyanı́nın su Ürünleri Fakültesine tahsisi.” Unpublished report.

Anand, Nikhil

2011 "Pressure: The PoliTechnics of Water Supply in Mumbai." Cultural Anthropology 26, no. 4: 542-64. https://doi.org/10.1111/j.1548-1360.2011.01111.x.

Anand, Nikhil, Akhil Gupta, and Hannah Appel, eds.

2018 The Promise of Infrastructure. Durham, N.C.: Duke University Press.

Appel, Hannah C.

2012 "Walls and White Elephants: Oil Extraction, Responsibility, and Infrastructural Violence in Equatorial Guinea." Ethnography 13, no. 4: 439-65. https://doi. org/10.1177/1466138111435741.

Arsel, Murat, Bengi Akbulut, and Fikret Adaman

2015 "Environmentalism of the Malcontent: Anatomy of an Anti-Coal Power Plant Struggle in Turkey." Journal of Peasant Studies 42, no. 2: 371-95. https://doi.org/1 0.1080/03066150.2014.971766.

Baker, Lauren, Samara Brock, Luisa Cortesi, Aysen Eren, Chris Hebdon, Francis Ludlow, Jeffrey Stoike, and Michael Dove

2017 "Mainstreaming Morality: An Examination of Moral Ecologies as a Form of Resistance." Journal for the Study of Religion, Nature and Culture 11, no. 1: 23-55. https://doi.org/10.1558/jsrnc.27506.

Barnes, Jessica, and Samer Alatout

2012 "Water Worlds: Introduction to the Special Issue of Social Studies of Science." Social Studies of Science 42, no. 4: 483-88. https://doi.org/10.1177/0306312712448524.

Bartu Candan, Ayfer, and Biray Kolluoğlu

2008 "Emerging Spaces of Neoliberalism: A Gated Town and a Public Housing Project in İstanbul." New Perspectives on Turkey 39: 5-46. https://doi.org/10.1017/ S0896634600005057. 
Biggs, David

2010 Quagmire: Nation-Building and Nature in the Mekong Delta. Seattle: University of Washington Press.

Bird Rose, Deborah

2010 "Flying Fox: Kin, Keystone, Kontaminant." Translated by Yumiko Tsumura. Manoa 22, no. 2: 175-90. https://muse.jhu.edu/article/407436.

Blackbourn, David

2007 The Conquest of Nature: Water, Landscape, and the Making of Modern Germany. New York: W. W. Norton.

Boylan, Michael, ed.

2014 Environmental Ethics. 2nd edition. Malden, Mass: Wiley.

Bruun Jensen, Casper

2017 "The Umwelten of Infrastructure: A Stroll along (and inside) Phnom Penh's Sewage Pipes.” Zinbun, no. 47: 147-59. https://doi.org/10.14989/225131.

Bubandt, Nils, and Anna Tsing

2018 "Feral Dynamics of Post-Industrial Ruin: An Introduction." Journal of Ethnobiology 38, no. 1: 1-7. https://doi.org/10.2993/0278-0771-38.1.001.

Campbell, Ben

2018 "Moral Ecologies of Subsistence and Labour in a Migration-Affected Community of Nepal." Journal of the Royal Anthropological Institute 24, S1: 151-65. https://doi. org/10.1111/1467-9655.12805.

Carse, Ashley

2012 "Nature as Infrastructure: Making and Managing the Panama Canal Watershed." Social Studies of Science 42, no. 4: 539-63. https://doi.org/10.1177/ 0306312712440166.

2017 "Infrastructure: How a Humble French Engineering Term Shaped the Modern World." In Infrastructures and Social Complexity: A Companion, edited by Penny Coleman, Leo Harvey, Casper Bruun Jensen, and Atsuro Morita, 27-39. New York: Routledge.

2017 A Moral Technology: Electrification as Political Ritual in New Delhi. Ithaca, N.Y.: Cornell University Press.

Cons, Jason

2018 "Staging Climate Security: Resilience and Heterodystopia in the Bangladesh Borderlands." Cultural Anthropology 33, no. 2: 266-94. https://doi.org/10.14506/ ca33.2.08.

Datta, Ayona

2014 "Gendered Nature and Urban Culture: The Dialectics of Gated Developments in Izmir, Turkey.” International Journal of Urban and Regional Research 38, no. 4: 1363-83. https://doi.org/10.1111/1468-2427.12081.

Doğer, Ersin

1997 Ilk insanlardan yunan işgaline kadar menemen ya da tarhaniyat tarihi. Izmir, Turkey: Sergi Yayınevi.

Dove, Michael, and Daniel Kammen

1997 "The Epistemology of Sustainable Resource Use: Managing Forest Products, Swiddens, and High-Yielding Variety Crops." Human Organization 56, no. 1: $91-$ Edelman, Marc 101. https://doi.org/10.17730/humo.56.1.1784408q35174516.

2005 "Bringing the Moral Economy Back in . . . to the Study of Twenty-First-Century Transnational Peasant Movements." American Anthropologist 107, no. 3: 331-45.

Egemen, Medih https://doi.org/10.1525/aa.2005.107.3.331.

1946 Türkiyede Tuzculuk ve Çamaltı Tuzlası. İstanbul: Tekel İnstitüleri Yayınları.

Erensü, Sinan

2018 "Powering Neoliberalization: Energy and Politics in the Making of a New Turkey." Energy Research and Social Science 41: 148-57. https://doi.org/10.1016/j. erss.2018.04.037. 
Erensü, Sinan, and Ozan Karaman

2016 "The Work of a Few Trees: Gezi, Politics and Space." International Journal of Urban and Regional Research 41, no. 1: 19-36. https://doi.org/10.1111/1468-2427.12387.

Erol, Emre

2016 The Ottoman Crisis in Western Anatolia: Turkey's Belle Epoque and the Transition to a Modern Nation State. London: I.B. Taurus.

Errington, Frederick, and Deborah Gewertz

2018 "Managing an Endangered Species: Palliative Care for the Pallid Sturgeon." American Ethnologist 45, no. 2: 186-200. https://doi.org/10.1111/amet.12631.

Evered, Kyle

2012 "Political Ecologies of Turkey's Wetlands and Lake Burdur: The Case of Demirel and the Duck." Arab World Geographer 15, no. 1: 45-71. https://arabworldgeographer. org/doi/abs/10.5555/arwg.15.1.x01264137077p8n7.

Farmer, Tessa Rose

2014 "Cairo Ecologies: Water in Social and Material Cycles." PhD dissertation, The University of Texas at Austin.

Fassin, Didier

2009 "Les économies morales revisitées." Annales. Histoire, Sciences Sociales 64, no. 6: 1237-66. https://www.jstor.org/stable/40929924.

Firat, Bilge

2016 “'The most eastern of the West, the most western of the East': Energy-Transport Infrastructures and Regional Politics of the Periphery in Turkey." Economic Anthropology 3, no. 1: 81-93. https://doi.org/10.1002/sea2.12046.

Fischer, Michael M. J.

1999 "Emergent Forms of Life: Anthropologies of Late or Postmodernities." Annual Review of Anthropology 28: 455-78. https://doi.org/10.1146/annurev. anthro.28.1.455.

Goffman, Daniel

1990 Izmir and the Levantine World, 1550-1650. Seattle: University of Washington Press. Gruppuso, Paolo

2018 "Edenic Views in Wetland Conservation: Nature and Agriculture in the Fogliano Area, Italy." Conservation and Society 16, no. 4: 397-408. https://doi.org/10.4103/ cs.cs_17_130.

Guarasci, Bridget L.

2015 "The National Park: Restoring the Marshes in Wartime Iraq." Arab Studies Journal 23, no. 1: 128-53.

Hart, Kimberly

2013 And Then We Work for God: Rural Sunni Islam in Western Turkey. Stanford, Calif.: Stanford University Press.

2017 "The Suburbanization of Rural Life in an Arid and Rocky Village in Western Turkey.” Journal of Arid Environments 149: 73-79. https://doi.org/10.1016/j. jaridenv.2017.03.011.

Harvey, Penny, and Hannah Knox

2012 "The Enchantments of Infrastructure." Mobilities 7, no. 4: 521-36. https://doi.org /10.1080/17450101.2012.718935.

2015 Roads: An Anthropology of Infrastructure and Expertise. Ithaca, N.Y.: Cornell University Press.

Hertzke, Allen D.

1998 "The Theory of Moral Ecology." Review of Politics 60, no. 4: 629-59. https://doi.

Hetherington, Kregg org/10.1017/S003467050005083X.

2019 "Keywords of the Anthropocene." In Infrastructure, Environment, and Life in the Anthropocene, edited by Kregg Hetherington, 1-16. Durham, N.C.: Duke University Press. 
Hoefle, Scott William

2008 "You Pig! A Regional Approach to Environmental Ethics in the Sertão of Northeast Brazil." Critique of Anthropology 28, no. 4: 376-405. https://doi. org/10.1177/0308275X08098258.

Howe, Cymene, Jessica Lockrem, Hannah Appel, Edward Hackett, Dominic Boyer, Randal

Hall, Matthew Schneider-Mayerson et al.

2016 "Paradoxical Infrastructures: Ruins, Retrofit, and Risk." Science, Technology, and Human Values 41, no. 3: 547-65. https://doi.org/10.1177/0162243915620017.

Hughes, Thomas P.

1987 "The Evolution of Large Technological Systems." In The Social Construction of Technological Systems: New Directions in the Sociology and History of Technology, edited by Wiebe E. Bijker, Thomas P. Hughes, and Trevor J. Pinch, 51-82. Cambridge, Mass.: MIT Press.

Husain, Faisal

2014 "In the Bellies of the Marshes: Water and Power in the Countryside of Ottoman Baghdad." Environmental History 19, no. 4: 638-64. https://doi.org/10.1093/ envhis/emu067.

Igoe, Jim, and Dan Brockington

2007 "Neoliberal Conservation: A Brief Introduction." Conservation and Society 5, no. 4: 432-49.

Ives, Sarah

2014 "Uprooting 'Indigeneity' in South Africa's Western Cape: The Plant that Moves." American Anthropologist 116, no. 2: 310-23. https://doi.org/10.1111/aman.12096.

Jax, Kurt, David N. Barton, Kai M. A. Chan, Rudolf de Groot, Ulrike Doyle, Uta Eser,

Christoph Görg, et al.

2013 "Ecosystem Services and Ethics." Ecological Economics 93: 260-68. https://doi. org/10.1016/j.ecolecon.2013.06.008.

Karademir Erol, Gamze

2012 “Körfezin son dalyanı: Homa koruma altında.” Egeden, Summer: 10-13.

Karakoyun, Umut

2018 “İzmir Körfez Geçişi’ne Durdurma: Flamingolara Iyi Haber.” Hürriyet, August 13. http://www.hurriyet.com.tr/gundem/izmir-korfez-gecisine-durdurma-flamingolaraiyi-haber-40927639.

Keane, Webb

2016 “A Reader's Guide to the Anthropology of Ethics and Morality: Part II." Somatosphere, October 28. http://somatosphere.net/2016/10/ethics-and-morality-part-2.html.

Kim, Eleana J.

2015 "Toward an Anthropology of Landmines: Rogue Infrastructure and Military Waste in the Korean DMZ." Cultural Anthropology 31, no. 2: 162-87. https://doi.

Kirksey, Eben org/10.14506/ca31.2.02.

2015 Emergent Ecologies. Durham, N.C.: Duke University Press.

Kızılkaya, Zafer

2012 “Homa Dalyanı'nın yeni yüzü.” Altas Dergisi, no. 234, September 28.

Knudsen, Ståle

2016 "Protests against Energy Projects in Turkey: Environmental Activism above Politics?” British Journal of Middle Eastern Studies 43, no. 3: 302-23. https://doi.org /10.1080/13530194.2015.1102707.

Kohler, Robert E.

2011 "Paul Errington, Aldo Leopold, and Wildlife Ecology: Residential Science." Historical Studies in the Natural Sciences 41, no. 2: 216-54. https://doi.org/10.1525/ hsns.2011.41.2.216.

Larkin, Brian

2008 Signal and Noise: Media, Infrastructure, and Urban Culture in Nigeria. Durham, N.C.: Duke University Press. 
Li, Tania Murray

2018 “After the Land Grab: Infrastructural Violence and the 'Mafia System' in Indonesia's Oil Palm Plantation Zones." Geoforum 96: 328-37. https://doi.org/10.1016/j.

Martínez-Reyes, José E. geoforum.2017.10.012.

2016 Moral Ecology of a Forest: The Nature Industry and Maya Post-Conservation. Tucson: University of Arizona Press.

Masco, Joseph

2004 “Mutant Ecologies: Radioactive Life in Post-Cold War New Mexico." Cultural Anthropology 19, no. 4: 517-50. https://doi.org/10.1525/can.2004.19.4.517.

Mathews, Andrew

2018 "Landscapes and Throughscapes in Italian Forest Worlds: Thinking Dramatically about the Anthropocene." Cultural Anthropology 33, no. 3: 386-414. https://doi. org/10.14506/ca33.3.05.

Matthews, Geoffrey Vernon Townsend

1993 The Ramsar Convention on Wetlands: Its History and Development. Gland, Switzerland: Ramsar Convention Bureau.

Mattingly, Cheryl, and Jason Throop

2018 "The Anthropology of Ethics and Morality." Annual Review of Anthropology 47: 47592. https://doi.org/10.1146/annurev-anthro-102317-050129.

Meichanetsidis, Vasileios Th.

2015 "The Genocide of the Greeks of the Ottoman Empire, 1913-1923: A Comprehensive Overview.” Genocide Studies International 9, no. 1: 104-73. https://

Milton, Giles doi.org/10.3138/gsi.9.1.06.

2008 Paradise Lost: Smyrna, 1922. The Destruction of a Christian City in the Islamic World. New York: Basic Books.

Morita, Atsuro

2017 "Multispecies Infrastructure: Infrastructural Inversion and Involutionary Entanglements in the Chao Phraya Delta, Thailand." Ethnos 82, no. 4: 738-57. https://doi.org/10.1080/00141844.2015.1119175.

Mueggler, Erik

2011 The Paper Road: Archive and Experience in the Botanical Exploration of West China and Tibet. Berkeley: University of California Press.

Muehlebach, Andrea

2012 The Moral Neoliberal: Welfare and Citizenship in Italy. Chicago: University of Chicago Press.

Neyzi, Leyla

2008 "Remembering Smyrna/Izmir: Shared History, Shared Trauma." History and Memory 20, no. 2: 106-27. https://doi.org/10.2979/his.2008.20.2.106.

Özesmi, Uygar

1999 "Conservation Strategies for Sustainable Resource Use in the Kızılırmak Delta in Turkey.” PhD dissertation, University of Minnesota.

Özkan, Hande

2018 "Remembering Zingal: State, Citizens, and Forests in Turkey." International Journal of Middle East Studies 50, no. 3: 493-511. https://doi.org/10.1017/ S0020743818000831.

Pandian, Anand

2009 Crooked Stalks: Cultivating Virtue in South India. Durham, N.C.: Duke University Press.

Paxson, Heather

2013 The Life of Cheese: Crafting Food and Value in America. Berkeley: University of California Press. 
Paxson, Heather, and Stefan Helmreich

2014 "The Perils and Promises of Microbial Abundance: Novel Natures and Model Ecosystems, from Artisanal Cheese to Alien Seas." Social Studies of Science 44, no.

Polanyi, Karl 2: 165-93. https://doi.org/10.1177/0306312713505003.

1957 The Great Transformation: The Political and Economic Origins of Our Time. New York: Farrar and Rinehart.

Pritchard, Sara B.

2011 Confluence: The Nature of Technology and the Remaking of the Rhône. Cambridge, Mass.: Harvard University Press.

Richardson, Tanya

2016 "Where the Water Sheds: Disputed Deposits at the Ends of the Danube." In Watersheds: Poetics and Politics of the Danube River, edited by Marijeta Bozovic and Matthew D. Miller, 308-37. Boston: Academic Studies Press.

Ritvo, Harriet

2009 The Dawn of Green: Manchester, Thirlmere, and Modern Environmentalism. Chicago: University of Chicago Press.

Rizvi, Mubbashir

2017 "The Moral Ecology of Colonial Infrastructure and the Vicissitudes of Land Rights in Rural Pakistan." History and Anthropology 28, no. 3: 308-25. https://doi.org/10. 1080/02757206.2016.1253566.

Saltan, Sevket, and Cahit Okar

1968 "A Summary of the Salt Industry in Turkey: Çamaltı Saltworks." Report. Rome: United Nations Industrial Development Organization.

Saxena, Alder Keleman, Deepti Chatti, Katy Overstreet, and Michael R. Dove

2018 "From Moral Ecology to Diverse Ontologies: Relational Values in Human Ecological Research, Past and Present." Current Opinion in Environmental Sustainability 35:

Scaramelli, Caterina 54-60. https://doi.org/10.1016/j.cosust.2018.10.021.

2018a "Fish, Flows, and Desire in the Delta." Anthropology News website, March 12. https://doi.org/10.1111/AN.795.

2018b “The wetland is disappearing': Conservation and Care on Turkey's Kızılırmak Delta." International Journal of Middle East Studies 50, no. 3: 405-25. https://doi. org/10.1017/S0020743818000788.

Schwenkel, Christina

2015 "Spectacular Infrastructure and Its Breakdown in Socialist Vietnam." American Ethnologist 42, no. 3: 520-34. https://doi.org/10.1111/amet.12145.

Scott, James C.

1977 The Moral Economy of the Peasant: Rebellion and Subsistence in Southeast Asia. New Haven, Conn.: Yale University Press.

2017 Against the Grain: A Deep History of the Earliest States. New Haven, Conn.: Yale Sıkı, Mehmet University Press.

1994 "Izmir kuş cennetinin tarihçesi." Tabiat ve insan 27, no. 1: 6-10.

1997 “Izmir kuşcenneti’nin dünü, bügünü, ve yarını.” In II kıyı sorunlar ve çevre sempozyumu [Proceedings of the Second Symposium on Coastal and Environmental Problems], November 14-16, edited by Ayşe Günbey Şerifoğlu, 748-56. Kuşadası, Turkey: Belediye Yayınları.

Sıkı, Mehmet, and Ibrahim Baran

1984 “Çamaltı tuzlası'ndaki 'kuş cenneti.”” Bilim ve teknik, April: 4-5.

Simone, AbdouMaliq

2004 "People as Infrastructure: Intersecting Fragments in Johannesburg." Public Culture 16, no. 3: 407-29. https://doi.org/10.1215/08992363-16-3-407.

Star, Susan Leigh

1999 “The Ethnography of Infrastructure." American Behavioral Scientist 43, no. 3: 377 91. https://doi.org/10.1177/00027649921955326. 
Stamatopoulou-Robbins, Sophia

2014 "Occupational Hazards." Comparative Studies of South Asia, Africa and the Middle East

Stoetzer, Bettina 34, no. 3: 476-96. https://doi.org/10.1215/1089201x-2826049.

2018 "Ruderal Ecologies: Rethinking Nature, Migration, and the Urban Landscape in Berlin." Cultural Anthropology 33, no. 2: 295-323. https://doi.org/10.14506/ ca33.2.09.

Swartz, Sharlene

2010 “'Moral Ecology' and 'Moral Capital': Tools towards a Sociology of Moral Education from a South African Ethnography." Journal of Moral Education 39, no 3: 305-27. https://doi.org/10.1080/03057240.2010.497611.

Takacs, David

1996 The Idea of Biodiversity: Philosophies of Paradise. Baltimore: John Hopkins University Press.

Thompson, E. P.

1971 "The Moral Economy of the English Crowd in the Eighteenth Century." Past and Present 50, no. 1: 76-136. https://doi.org/10.1093/past/50.1.76.

Throop, C. Jason

2016 "A Reader's Guide to the Anthropology of Ethics and Morality: Part I." Somatosphere, September 30. http://somatosphere.net/2016/09/part-i.html.

Tsing, Anna Lowenhaupt

2015 The Mushroom at the End of the World: On the Possibility of Life in Capitalist Ruins. Princeton, N.J.: Princeton University Press.

von Schnitzler, Antina

2013 "Traveling Technologies: Infrastructure, Ethical Regimes, and the Materiality of Politics in South Africa." Cultural Anthropology 28, no. 4: 670-93. https://doi.

Voulvouli, Aimilia org/10.1111/cuan.12032.

2009 From Environmentalism to Transenvironmentalism: The Ethnography of an Urban Protest

White, Richard in Modern Istanbul. New York: Peter Lang.

1996 The Organic Machine: The Remaking of the Columbia River. New York: Hill and Wang. Williams, Raymond

1977 "Dominant, Residual, and Emergent." In Marxism and Literature, 121-27. New York: Oxford University Press.

Yates, Julian S., Leila M. Harris, and Nicole J. Wilson

2017 "Multiple Ontologies of Water: Politics, Conflict, and Implications for Governance." Environment and Planning D 35, no. 5: 797-815. https://doi. org/10.1177/0263775817700395.

Yazıcı, Meryem, and Baha Büyükıșık

2007 "Homa Dalyanı (İzmir Körfezi, Ege Denizi)'nda sekonder prodüktivitenin Yeh, Emily T. araştırılması." Su ürünleri dergisi 24, nos. 3-4: 267-72.

2009 "From Wasteland to Wetland? Nature and Nation in China's Tibet." Environmental

Zandi-Sayek, Sibel History 14, no. 1: 103-37. https://doi.org/10.1093/envhis/14.1.103.

2012 Ottoman Izmir: The Rise of a Cosmopolitan Port, 1840-1880. Minneapolis: University of Minnesota Press. 